\title{
KAJIAN KUALITAS DAYA LISTRIK PLTS SISTEM OFF-GRID DI STT-PLN
}

\author{
Aas Wasri Hasanah ${ }^{1)}$, Tony Koerniawan ${ }^{2)}$, Yuliansyah ${ }^{3)}$ \\ Teknik Elektro, Sekolah Tinggi Teknik - PLN \\ 1aas_wasri@yahoo.com \\ 2tonykoerniawan84@gmail.com \\ 3yansyah62@gmail.com
}

\begin{abstract}
Inadequate power quality causes damage and may even cause damage to electrical equipment. Solar Power Plants Off-grid is a stand-alone power plant is not connected to the network. This system uses storage media such as batteries to maintain the availability of electricity at night or when the sun's intensity decreases. Solar power plant has a PV module that works based on the intensity of the captured sunlight and the inverter that can change the dc voltage into ac where as is known in the inverter there are non linear components which can result in poor quality of electrical power in this case the total harmonic distortion and voltage variations change. This may result in damage to electrical equipment. The electrical power quality of the STT-PLN off-grid PLTS will be analyzed and compared with the IEEE 519-1992 and SPLN 1: 1995 standards. Based on the results of the discussion that the THDi and THDv values are still above the established standard limit of $5 \%$.
\end{abstract}

Keywords: Electrical power quality, Off-Grid PLTS, THD, voltage

\begin{abstract}
ABSTRAK
Kualitas daya listrik yang tidak memadai menyebabkan tidak berfungsinya dan bahkan dapat menyebabkan kerusakan pada peralatan listrik. Pembangkit listrik tenaga surya (PLTS) Off-grid merupakan pembangkit listrik yang berdiri sendiri/stand alone tidak terhubung ke jaringan. Sistem ini menggunakan media penyimpanan seperti baterai untuk menjaga ketersediaan listrik ketika malam hari maupun ketika intensitas matahari menurun. PLTS memiliki modul PV yang bekerja berdasarkan intensitas sinar matahari yang ditangkap dan inverter yang dapat merubah tegangan DC menjadi AC dimana seperti yang diketahui di dalam inverter terdapat komponen-komponen non linier yang dapat mengakibatkan buruknya kualitas daya listrik dalam hal ini total harmonik distorsi dan variasi tegangan berubah-ubah. Hal ini dapat mengakibatkan kerusakan pada peralatan listrik. Kualitas daya listrik dari PLTS Off-Grid STT-PLN akan dianalisis dan dibandingkan dengan standar IEEE 519-1992 dan SPLN 1:1995. Berdasarkan hasil pembahasan bahwa nilai THDi dan THDv masih di atas batas standar yang ditetapkan yaitu sebesar 5\%.
\end{abstract}

Kata Kunci : Kualitas daya listrik, PLTS Off-Grid, THD, tegangan. 


\section{PENDAHULUAN}

Indonesia memiliki potensi sumber energi terbarukan dalam jumlah yang besar. Diantara sumber-sumber energi tersebut, energi surya termasuk salah satu sumber energi yang tidak terbatas dan paling banyak digunakan sebagai sumber energi untuk membangkitkan listrik. Indonesia merupakan tergolong negara yang kaya dengan sumber energi matahari. Di samping itu, karena letaknya di khatulistiwa, intensitas matahari pada Indonesia perhari berkisar $1200 \mathrm{w} / \mathrm{m} 2$.

Sistem PLTS yang diterapkan adalah sistem pembangkit listrik yang tidak terhubung dengan jaringan atau yang disebut PLTS Off-Grid. Dengan sistem pengaturan yang baik PLTS ini dapat digunakan sebagai pembangkit listrik yang handal. Dalam pemanfaatan PLTS sebagai pembangkit tenaga listrik cadangan, daya yang dihasilkan panel surya tidak stabil, mengkhawatirkan kualitas daya listrik yang dihasilkan PLTS tidak baik, hal ini tergantung pada intensitas sinar matahari yang diterima oleh panel surya. Dan terdapat pula inverter bi-directional yang dapat mengubah sumber DC menjadi AC begitu juga sebaliknya, yang dikhawatirkan dapat menimbulkan harmonisa, karena di dalam inverter terdapat komponen-komponen non linier yang dapat mengakibatkan buruknya kualitas daya listrik yang dihasilkan. Dengan menempatkan suatu sistem pengaturan yang baik buruknya kualitas daya listrik ini bisa diatasi.

Penelitian ini adalah mengkaji kualitas daya listrik PLTS Off-grid di STT-PLN untuk mengetahui seberapa bagusnya kualitas daya listrik yang dihasilkan sistem tersebut dengan standar yang ditetapkan, sehingga dapat digunakan sebagai referensi dan tindaklanjut di dalam pembangunan dan pengembangan PLTS ke depan menjadi lebih baik.

\subsection{Konfigurasi PLTS}

Pada sistem pembangkit listrik tenaga surya konfigurasi terhadap jaringan yang terhubung dibedakan menjadi tiga, yaitu sistem PLTS yang dihubungkan langsung dengan jaringan PLN atau biasa disebut PLTS On-Grid. Sistem PLTS yang tidak dihubungkan kejaringan PLN atau yang biasa disebut PLTS Off-Grid/Stand-Alone. Dan PLTS yang sistemnya digabung dengan jenis pembangkit lain atau biasa disebut sistem PLTS Hybrid.

\subsubsection{PLTS On Grid}

Sistem PLTS terinterkoneksi (On-Grid) atau yang disebut dengan Grid Connected PV System adalah sistem pembangkit listrik yang memanfaatkan radiasi matahari untuk menghasilkan listrik. Dan sesuai dengan namanya, maka sistem ini akan dihubungkan dengan jaringan PLN dengan mengoptimalkan pemanfaatkan energi matahari melalui modul surya atau photovoltaic modul yang menghasilkan listrik semaksimal mungkin. Sistem ini juga dianggap ramah lingkungan dan bebas emisi. Sistem PLTS terinterkoneksi juga merupakan sebuah solusi green energi bagi masyarakat perkotaan baik perkantoran maupun perumahan yang bertujuan untuk dapat memperkecil tagihan rekening listrik dari PLN dan dapat memberikan nilai tambah kepada pemiliknya. 


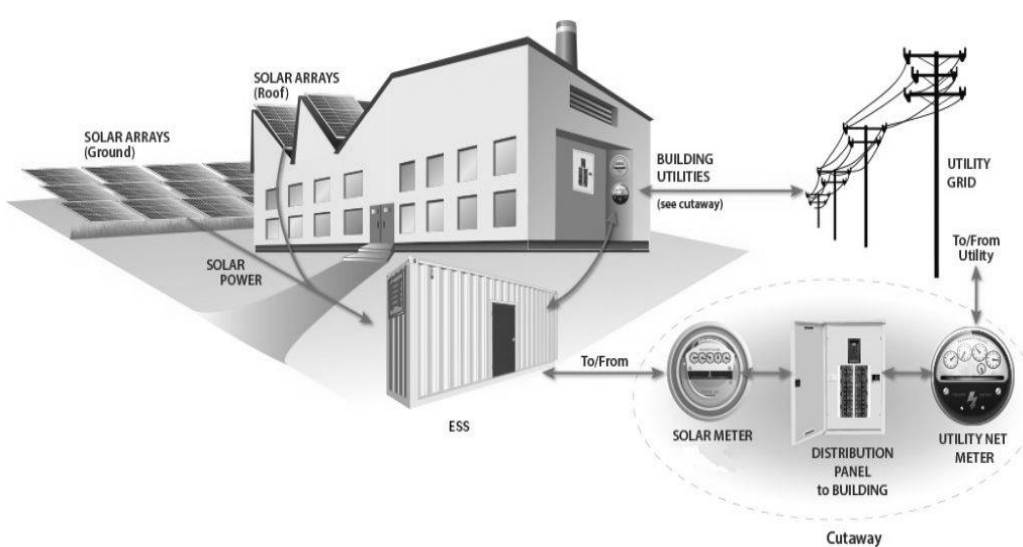

Gambar 1. PLTS On-Grid

\subsubsection{PLTS Off Grid}

Sistem Pembangkit Listrik Tenaga Surya Terpusat (Off-Grid) merupakan sistem pembangkit listrik yang memanfaatkan radiasi matahari tanpa terhubung dengan jaringan PLN atau dengan kata lain satu-satunya sumber pembangkitnya yaitu hanya menggunakan radiasi matahari dengan bantuan panel surya atau photovoltaic untuk dapat menghasilkan energi listrik sistem PLTS OffGrid sendiri juga hanya dimanfaatkan untuk daerah yang tidak terjangkau pasokan listrik dari PLN seperti daerah pedesaan.

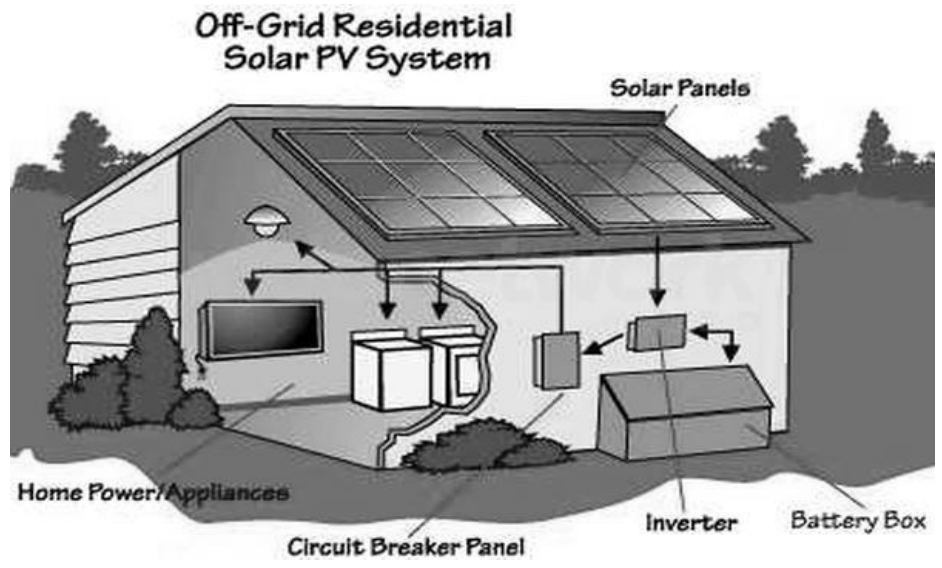

Gambar 2. PLTS Off-Grid

\subsection{Kualitas Daya}

Sistem tenaga listrik dituntut menghasilkan daya listrik yang berkualitas, terutama untuk menyuplai suatu beban yang penting dan sensitif. Masalah kualitas daya listrik meliputi setiap masalah yang berhubungan dengan tegangan, arus atau deviasi frekuensi yang menyebabkan kegagalan atau kesalahan pengoperasian pada peralatan listrik yang digunakan. Jenis gangguan kualitas daya tersebut antara lain adalah: steady state, transient, ossilator, interupsi, sag/undervoltage, swell atau overvoltage, DC offset, harmonisa, interharmonisa, noise, fluktuasi tegangan, dan variasi frekuensi. Kualitas daya listrik ini sangat terkait dengan tegangan suplai. Naik turunnya tegangan pada batas-batas tertentu mengakibatkan terjadinya kerusakan pada peralatan produksi ataupun hasil produksi. Untuk itu perlu dilakukan berbagai upaya guna menjaga atau memperbaiki kualitas daya listrik. 
Tabel 1. Standar Tegangan SPLN 1: 1995

\begin{tabular}{|c|c|}
\hline $\begin{array}{c}\text { Tegangan Nominal } \\
(\mathrm{V})\end{array}$ & $\begin{array}{c}\text { Variasi Tegangan } \\
\text { Pelayanan }(\%)\end{array}$ \\
\hline $230 / 400$ & \\
$400 / 690$ & $+5 \%$ dan $-10 \%$ \\
1000 & \\
\hline
\end{tabular}

\subsection{Total Harmonic Distortion (THD)}

Faktor distorsi menggambarkan tingkat gangguan harmonik pada jaringan listrik. Ada beberapa pengukuran yang umum digunakan, salah satu yang paling umum adalah distorsi harmonik total (THD) yang akan digunakan dalam penelitian ini, untuk tegangan ataupun arusnya.

$$
T H D=\frac{\sqrt{M_{h>1}^{2}}}{M_{1}} 100
$$

Dimana :

THD $=$ Total Harmonik Distortion

$\mathrm{Mh}=$ Nilai RMS dari arus atau tegangan dari komponen harmonik ke-h

M1 = Nilai RMS dari arus atau tegangan dari frekuensi dasar

Ada berbagai batas distorsi harmonik di beberapa negara. Kebanyakan Industri menggunakan batas distorsi yang dikeluarkan oleh IEEE std-519-1992.

Tabel 2. Batas Distorsi Arus (120 V Sampai $69 \mathrm{kV}$ )

\begin{tabular}{|c|c|c|c|c|c|c|}
\hline \multicolumn{7}{|c|}{ Distorsi arus harmonik maksimum $\left(\mathrm{I}_{\mathrm{h}} \%\right.$ dari $\left.\mathrm{I}_{\mathrm{L}}\right)$} \\
\hline $\mathrm{I}_{\mathrm{sc}} / \mathrm{I}_{\mathrm{L}}$ & $<11$ & $11 \leq \mathrm{h}<17$ & $17 \leq \mathrm{h}<23$ & $23 \leq \mathrm{h}<35$ & $\mathrm{~h} \geq 35$ & THDi \\
\hline$<20$ & 4.0 & 2.0 & 1.5 & 0.6 & 0.3 & 5.0 \\
\hline $20<50$ & 7.0 & 3.5 & 2.5 & 1.0 & 0.5 & 8.0 \\
\hline $50<100$ & 10.0 & 4.5 & 4.0 & 1.5 & 0.7 & 12.0 \\
\hline
\end{tabular}

Tabel 3. Batas Distorsi Tegangan

\begin{tabular}{|c|c|c|}
\hline $\begin{array}{c}\text { Tegangan Bus pada } \\
\text { PCC }\end{array}$ & $\begin{array}{c}\text { Batas harmonik } \\
\text { individual }(\%)\end{array}$ & $\begin{array}{c}\text { THDV } \\
(\%)\end{array}$ \\
\hline $\mathrm{V} \leq 69 \mathrm{kV}$ & 3 & 5 \\
\hline $69 \mathrm{kV}<\mathrm{V}<161 \mathrm{kV}$ & 1.5 & 2.5 \\
\hline $\mathrm{V} \geq 161 \mathrm{kV}$ & 1 & 1.5 \\
\hline
\end{tabular}

\section{METODE PENELITIAN}

\subsection{Blok Diagram Pengambilan Data}

Metode yang dilakukan yaitu melakukan pengamatan PLTS secara langsung ke lapangan dan melakukan pengambilan data dari PLTS Off-Grid di STT-PLN dengan menggunakan alat ukur harmonik HIOKI 3286-20 (digunakan untuk mengukur harmonik arus dan tegangan). 


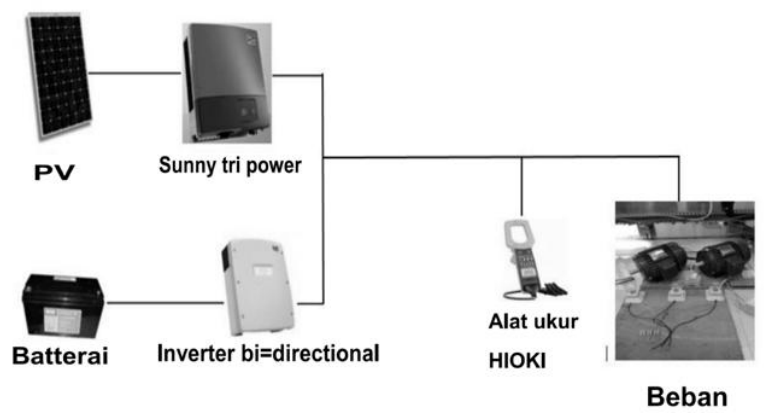

Gambar 3. Blok Diagram Pengambilan Data

\subsection{Diagram Alir Penelitian}

Berikut adalah diagram alir penelitian yang dilakukan:

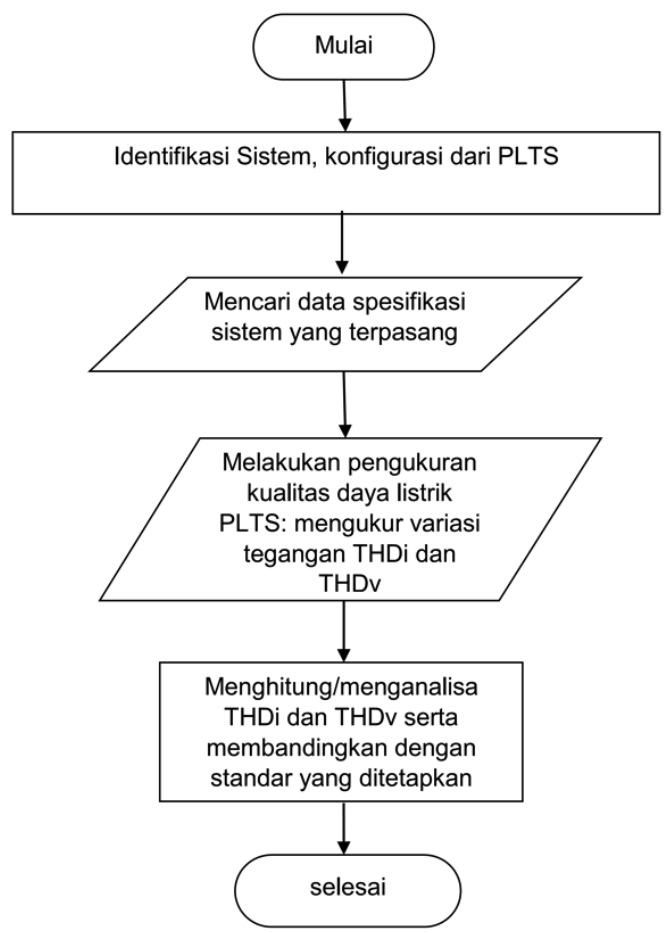

Gambar 4. Diagram Alir Penelitian PLTS Off-Grid di STT-PLN.

\section{HASIL DAN PEMBAHASAN}

\subsection{Spesifikasi Sistem PLTS Off-grid STT-PLN}

Konfigurasi sistem PLTS STT-PLN tersusun dari komponen-komponen utama seperti rangkaian modul, baterai, inverter (bi-directional inverter). 
Tabel 4. Data spesifikasi Modul Surya PLTS STT-PLN

\begin{tabular}{|l|c|}
\hline Merk & Suntech \\
\hline Modul Name & STP $260-20 \mathrm{Wem}$ \\
\hline Maximum Power & $260 \mathrm{Wp}$ \\
\hline Short Circuit Current $\left(\mathrm{S}_{\mathrm{SC}}\right)$ & $8,89 \mathrm{~A}$ \\
\hline Current at $\mathrm{P}_{\max }\left(\mathrm{I}_{\mathrm{mp}}\right)$ & $8,42 \mathrm{~A}$ \\
\hline Open Circuit Voltage $\left(\mathrm{V}_{\mathrm{OC}}\right)$ & $37,7 \mathrm{~V}$ \\
\hline Voltage at $\mathrm{P}_{\max }\left(\mathrm{V}_{\mathrm{mp}}\right)$ & 30,9 \\
\hline Maximum System Voltage & DC $1000 \mathrm{~V}(\mathrm{IEC})$ \\
\hline Power Tollerance & $\pm 5 \%$ \\
\hline Temperature Range & -40 to $+85^{\circ} \mathrm{C}$ \\
\hline Dimensions & $160 \times 992 \times 35 \mathrm{~mm}$ \\
\hline Cell Technology & Poly Crystalline \\
\hline Weight & $18,20 \mathrm{Kg}$ \\
\hline
\end{tabular}

\subsection{Analisis Total Harmonik Distorsi THDi dan THDv}

Untuk mengetahui kualitas daya listrik yang dihasilkan PLTS STT-PLN keluaran dari inverter sunny island dapat dihitung dan dianalisis dari data-data hasil pengukuran langsung.

Tabel 5. Data Pengukuran Harmonik Pada PLTS Keluaran Inverter Sunny Island

\begin{tabular}{|c|c|c|c|c|c|c|c|}
\hline \multicolumn{2}{|c|}{ Beban Lampu Pijar } \\
\hline $\begin{array}{c}\text { Arus } \\
\text { Harmonik }\end{array}$ & $\begin{array}{c}\mathrm{R} \\
\text { (Ampere) }\end{array}$ & $\begin{array}{c}\mathrm{S} \\
\text { (Ampere) }\end{array}$ & $\begin{array}{c}\mathrm{T} \\
\text { (Ampere) }\end{array}$ & $\begin{array}{c}\text { Tegangan } \\
\text { Harmonik }\end{array}$ & $\begin{array}{c}\mathrm{R}-\mathrm{S} \\
\text { (Volt) }\end{array}$ & $\begin{array}{c}\mathrm{R}-\mathrm{T} \\
\text { (Volt) }\end{array}$ & $\begin{array}{c}\mathrm{S}-\mathrm{T} \\
\text { (Volt) }\end{array}$ \\
\hline 1 & 1.82 & 1.97 & 2.06 & 1 & 400 & 399 & 400 \\
\hline 3 & 0.03 & 0.03 & 0.04 & 3 & 1 & 2 & 1 \\
\hline 5 & 0.05 & 0.05 & 0.05 & 5 & 4 & 3 & 4 \\
\hline 7 & 0 & 0 & 0 & 7 & 1 & 1 & 1 \\
\hline 9 & 0 & 0 & 0 & 9 & 0 & 0 & 0 \\
\hline 11 & 0 & 0 & 0 & 11 & 0 & 0 & 0 \\
\hline 15 & 0 & 0 & 0 & 15 & 0 & 0 & 0 \\
\hline 13 & 0 & 0 & 0 & 13 & 0 & 0 & 0 \\
\hline 17 & 0 & 0 & 0 & 17 & 0 & 0 & 0 \\
\hline 19 & 0 & 0 & 0 & 19 & 0 & 0 & 0 \\
\hline
\end{tabular}

Tabel 6. Data Pengukuran Harmonik Pada PLTS Keluaran Inverter Sunny Island

\begin{tabular}{|c|c|c|c|c|c|c|c|}
\hline \multicolumn{8}{|c|}{ Beban Motor 3 Fasa } \\
\hline $\begin{array}{c}\text { Arus } \\
\text { Harmonik }\end{array}$ & $\begin{array}{c}\mathbf{R} \\
\text { (Ampere) }\end{array}$ & $\begin{array}{c}\mathbf{S} \\
\text { (Ampere) }\end{array}$ & $\begin{array}{c}\mathbf{T} \\
\text { (Ampere) }\end{array}$ & $\begin{array}{l}\text { Tegangan } \\
\text { Harmonik }\end{array}$ & $\begin{array}{l}\mathbf{R}-\mathbf{S} \\
\text { (Volt) }\end{array}$ & $\begin{array}{l}\mathbf{R}-\mathbf{T} \\
\text { (Volt) }\end{array}$ & $\begin{array}{l}\text { S-T } \\
\text { (Volt) }\end{array}$ \\
\hline 1 & 0.42 & 0.42 & 0.43 & 1 & 231.5 & 228.8 & 230 \\
\hline 3 & 0.01 & 0.01 & 0.01 & 3 & 1.2 & 1.4 & 1.4 \\
\hline 5 & 0 & 0 & 0 & 5 & 0.2 & 0.2 & 0.4 \\
\hline 7 & 0 & 0 & 0 & 7 & 0.2 & 0.2 & 0.2 \\
\hline 9 & 0 & 0 & 0 & 9 & 0.2 & 0.2 & 0.1 \\
\hline 11 & 0 & 0 & 0 & 11 & 0.2 & 0.2 & 0.3 \\
\hline 13 & 0 & 0 & 0 & 13 & 0.1 & 0.1 & 0.3 \\
\hline 15 & 0 & 0 & 0 & 15 & 0.1 & 0 & 0.1 \\
\hline 17 & 0 & 0 & 0 & 17 & 0.1 & 0 & 0 \\
\hline 19 & 0 & 0 & 0 & 19 & 0.1 & 0 & 0.1 \\
\hline
\end{tabular}


Hasil perhitungan dan analisis dari data tersebut akan dibandingkan dengan standar IEEE 5191992 sebagai acuan untuk menentukan kualitas daya listrik dari PLTS STT-PLN. Untuk menghitung Total Harmonik Distorsi arus (THDi) menggunakan formula yang telah dibahas pada pembahasan sebelumnya. Sehingga, pada beban motor THDi yang dihasilkan:

pada fasa R $\quad T H D_{i}=\frac{\sqrt{{ }_{h>1} 0.08_{h}^{2}}}{1.82_{1}} \quad 100=4.4 \%$

pada fasa $S \quad T H D_{i}=\frac{\sqrt{{ }_{h>1} 0.08_{h}^{2}}}{1.97_{1}} \quad 100=4.19 \%$

pada fasa $\mathrm{T} T H D_{i}=\frac{\sqrt{{ }_{h>1} 0.09_{h}^{2}}}{2.06_{1}} \quad 100=4.3 \%$

Pada beban lampu pijar THDi yang dihasilkan :

pada fasa R $\quad T H D_{i}=\frac{\sqrt{{ }_{h>1} 0.01_{h}^{2}}}{0.42_{1}} \quad 100=2.4 \%$

pada fasa $S \quad T H D_{i}=\frac{\sqrt{{ }_{h>1} 0.01_{h}^{2}}}{0.42_{1}} \quad 100=2.4 \%$

pada fasa $\mathrm{T} T H D_{i}=\frac{\sqrt{{ }_{h>1} 0.01_{h}^{2}}}{0.43_{1}} \quad 100=2.3 \%$

Tabel 7. Harmonik Arus Keluaran Bi-Directional Inverter

\begin{tabular}{|c|c|c|c|c|c|c|c|}
\hline \multicolumn{4}{|c|}{ Beban Motor 3 Fasa } & \multicolumn{4}{c|}{ Beban Lampu Pijar } \\
\hline $\begin{array}{c}\text { Arus } \\
\text { Harmonik }\end{array}$ & $\begin{array}{c}\mathbf{R} \\
(\mathbf{A m p})\end{array}$ & $\begin{array}{c}\text { S } \\
(\mathbf{A m p})\end{array}$ & $\begin{array}{c}\text { T } \\
(\mathbf{A m p})\end{array}$ & $\begin{array}{c}\text { Tegangan } \\
\text { Harmonik }\end{array}$ & $\begin{array}{c}\mathbf{R} \\
(\mathbf{A m p})\end{array}$ & $\begin{array}{c}\text { S } \\
(\mathbf{A m p})\end{array}$ & $\begin{array}{c}\text { T } \\
(\mathbf{A m p})\end{array}$ \\
\hline 1 & 1.82 & 1.97 & 2.06 & 1 & 0.42 & 0.42 & 0.43 \\
\hline 3 & 0.03 & 0.03 & 0.04 & 3 & 0.01 & 0.01 & 0.01 \\
\hline 5 & 0.05 & 0.05 & 0.05 & 5 & 0 & 0 & 0 \\
\hline 7 & 0 & 0 & 0 & 7 & 0 & 0 & 0 \\
\hline 9 & 0 & 0 & 0 & 9 & 0 & 0 & 0 \\
\hline 11 & 0 & 0 & 0 & 11 & 0 & 0 & 0 \\
\hline 13 & 0 & 0 & 0 & 13 & 0 & 0 & 0 \\
\hline 15 & 0 & 0 & 0 & 15 & 0 & 0 & 0 \\
\hline 17 & 0 & 0 & 0 & 17 & 0 & 0 & 0 \\
\hline 19 & 0 & 0 & 0 & 19 & 0 & 0 & 0 \\
\hline 3 s.d 19 & 0.08 & 0.08 & 0.09 & 3 s.d 19 & 0.01 & 0.1 & 0.01 \\
\hline 1 s.d 19 & 1.9 & 2.05 & 2.15 & 1 s.d 19 & 0.43 & 0.43 & 0.43 \\
\hline THD $_{\mathrm{i}}$ & $4.4 \%$ & $4.1 \%$ & $4.3 \%$ & & $2.4 \%$ & $2.4 \%$ & $2.3 \%$ \\
\hline
\end{tabular}


Tabel 8. Harmonik Tegangan Keluaran Bi-Directional Inverter

\begin{tabular}{|c|c|c|c|c|c|c|c|}
\hline \multicolumn{4}{|c|}{ Beban Motor 3 Fasa } & \multicolumn{4}{c|}{ Beban Lampu Pijar } \\
\hline $\begin{array}{c}\text { Arus } \\
\text { Harmonik }\end{array}$ & $\begin{array}{c}\text { R } \\
\text { (Amp) }\end{array}$ & $\begin{array}{c}\text { S } \\
\text { (Amp) }\end{array}$ & $\begin{array}{c}\text { T } \\
\text { (Amp) }\end{array}$ & $\begin{array}{c}\text { Tegangan } \\
\text { Harmonik }\end{array}$ & $\begin{array}{c}\text { R } \\
\text { (Amp) }\end{array}$ & $\begin{array}{c}\text { S } \\
\text { (Amp) }\end{array}$ & $\begin{array}{c}\text { T } \\
\text { (Amp) }\end{array}$ \\
\hline 1 & 1 & 1 & 1 & 1 & 231 & 228.8 & 230 \\
\hline 3 & 4 & 3 & 3 & 3 & 1.2 & 1.4 & 1.4 \\
\hline 5 & 1 & 2 & 2 & 5 & 0.2 & 0.2 & 0.4 \\
\hline 7 & 0 & 0 & 0 & 7 & 0.2 & 0.2 & 0.2 \\
\hline 9 & 0 & 0 & 0 & 9 & 0.2 & 0.2 & 0.1 \\
\hline 11 & 0 & 0 & 0 & 11 & 0.1 & 0.2 & 0.3 \\
\hline 13 & 0 & 0 & 0 & 13 & 0.1 & 0.1 & 0.3 \\
\hline 15 & 0 & 0 & 0 & 15 & 0.1 & 0 & 0.1 \\
\hline 17 & 0 & 0 & 0 & 17 & 0.1 & 0 & 0 \\
\hline 19 & 0 & 0 & 0 & 19 & 0.1 & 0 & 0.1 \\
\hline 3 s.d 19 & 6 & 6 & 6 & 3 s.d 19 & 2.4 & 2.3 & 2.9 \\
\hline 1 s.d 19 & 406 & 404 & 404 & 1 s.d 19 & 233.4 & 231.1 & 232.9 \\
\hline THD & $4.4 \%$ & $4.1 \%$ & $4.3 \%$ & & $1 \%$ & $1 \%$ & $1.2 \%$ \\
\hline
\end{tabular}

Dari hasil perhitungan yang didapat pada THD tegangan, THDv pada beban motor didapat paling besar $1,5 \%$ sedangkan pada beban lampu 1,2\%. Dalam hal ini kualitas daya listrik yang dihasilkan inverter sunny island masih baik dan tidak berbeda jauh dari hasil pengukuran yang didapat sekitar 1,5\%, jika dibandingkan dengan standar IEEE 519-1992. Meskipun di dalam inverter terdapat komponen-komponen non linier yang dapat mengakibatkan terjadinya harmonik dari hasil analisa menunjukan hasil THDi dan THDv yang terjadi masih bagus di bawah standar yang ditetapkan IEEE 519-1992. Hasil pengukuran tegangan listrik memberikan kisaran tegangan antara 398 Volt - 399 Volt pada beban motor dan 228,8 Volt - 231 Volt pada beban lampu pijar yang menunjukan bahwa nilai tegangan masih sesuai dengan standar yang diizinkan SPLN 1:1995 $(+5 \%$ dan $-10 \%$

\section{KESIMPULAN}

Dari hasil analisis yang telah dilakukan, maka kesimpulan yang didapat dari penelitian ini, yaitu:

1. Berdasarkan hasil pengukuran dan perhitungan pada beban motor 3 fasa dengan daya $1,5 \mathrm{~kW}$ dan 3 buah lampu pijar dengan daya 100 Watt, nilai total harmonik distorsi arus (THDi) pada tiap-tiap fasanya yaitu pada beban motor 3 fasa THDi terkecil 4,1\% dan terbesar 4,4\% sedangkan pada beban lampu pijar THDi terkecil 2,3\% dan terbesar 2,4\%. Berdasarkan hasil perhitungan pada masing-masing beban bahwa nilai THDi masih di atas batas standar yang ditetapkan IEEE 519-1992 sebesar 5\%.

2. Hasil pengukuran dan perhitungan nilai total harmonik distorsi tegangan (THDv) pada masing-masing beban memiliki THDv terkecil $1 \%$ dan terbesar 1,5\%. Hasil perhitungan menyatakan bahwa nilai THDv masih di atas batas standar yang ditetapkan IEEE 519-1992 sebesar $5 \%$.

3. Hasil pengukuran tegangan listrik memberikan kisaran tegangan antar 398 Volt -399 Volt pada beban motor 3 fasa dan 228,8 Volt - 231 Volt pada beban lampu pijar yang menunjukan bahwa nilai tegangan yang terukur masih sesuai batas acuan yang diizinkan SPLN 1:1995 (+5\% dan $-10 \%)$. 


\section{UCAPAN TERIMA KASIH}

Penulis mengucapkan terima kasih kepada Sekolah Tinggi Teknik PLN yang telah memberi dukungan yang membantu pelaksanaan penelitian dan atau penulisan artikel.

\section{REFERENSI}

[1] Ambrish Chandra, Bhim Singh, B.N. Singh and Kamal-Al-Haddad, 2000, "An improved control algorithm of shunt active filter for voltage regulation, harmonic elimination, powerfactor correction, and balancing of nonlinear loads" IEEE Trans on Power Electronics Vol. 15, no 3, pp 495 - 507.

[2] Arrilangga J., Bradley, D.A, Bodger, P S, 1985, Power System Harmonic, New York, John Willey\&Sons.

[3] Dugan Roger C, Mark F McGranaghan and H Wayne Beaty. 1996. Electrical Power Systems, Mc Graw-Hill.

[4] Dunlop, James P. 1997. Batteries and charge control in stand-Alone Photovoltaic System Fundamentals and Applications. Cocoa: Florida Energy Center.

[5] Irawati Rina 2013, "Micro-Grid PLTS, Batere dan PLN Untuk Menjaga Kualitas Daya di Industri”.

[6] IEEE Load Characteristics Task Force, 1985, The effect of The Power System Harmonics and Power System Equipment and Load, IEEE Trans. Power App, Sys. Vol 104.

[7] Kementrian ESDM. 2016. Rencana Usaha Penyediaan Tenaga Listrik PT. Perusahaan Listrik Negara (Persero) tahun 2016-2025. 